\title{
“北京人”遗址灰烬物质热发光 年龄及其地质意义
}

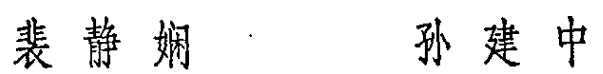 \\ (中国科学院地质研究所)（国家地震局地质研究所）
}

随着热发光机制的研究及辐射剂量学的发展,热发光技术近年来已有效地应用于核物理、 放射医学、地质、考古等方面, 并在地质、考古年龄测定中取得了一定的进展. 根据热发光测定 年龄原理,燃烧烘烤后的沉积物辐射剂量从零开始累积. 累积量与时间成正比,因而用热发光 方法测定地质年龄是行之有效的. 我们对周口店“北京人”遗址第一地点上、下文化层的灰烬 物质及第四地点灰烬物质用石英包体法进行了热发光测定年龄。其结果分别为 29 万年(上文 化层)、61 万年 (下文化层)、24-28 万年 (第四地点). 这些年龄数据与前人所做的古人类、 化、古生物及近年来所做的古地磁、氨基酸和第四纪地层等项研究结果基本吻合.

我国许多地区新生代玄武岩多次间歇性喷发形成多期不同时代的烘烤层.如大同火山群、 五大连池、长白山、睠冲、河北省井隆、海南药等地均有多期烘烤层. 这种现象对进一步划分新 生代和第四纪地层具有很大意义. 尤其是我们用热发光方法测定“北京人”遗址灰烬物质的绝 对年龄取得比较理想的结果, 说明将这个方法用在测定烘烤沉积物绝对年龄方面也具有广阔 的前景.

\section{THERMOLUMINESCENCE AGES OF QUARTZ IN ASH MATERIALS FROM HOMO ERECTUS PEKINOSIS SITE AND ITS GEOLOGICAL IMPLICATION}

\author{
Pei Jing-xian (裴静沭) and Sun Jian-zhong(孙建中)
}

\begin{abstract}
The thermoluminescence ages of 5 quartz samples extracted from ash materials are determined by the inclusion method. The average age of the two samples collected from the upper cultural layer of Locality No. 1 has been estimated at $0.30 \mathrm{~m} . \mathrm{y}$. The ages of two other samples taken from the lower cultural layer at the same locality have been estimated at 0.52 and $0.61 \mathrm{~m} . y$. respectively. The thermoluminescence age of a sample from Locality No. 4 has been found to be $0.32 \mathrm{~m} . \mathrm{y}$. These results are essentially in agreement with previous datings. They indicate that the TL intensities of the materials burned and baked were accumulated from their last heating events and are directly proportional to the time ever afterwards. This same method can also be used for the determination of TL ages of sediments burned or baked by Cenozoic lava flows.
\end{abstract}

本文 1979 年 2 月 17 日收到. 